The most notable phenomenon visible during the Indian eclipse was the Great Horn visible in Fig. 3, the structure of which was extremely curious. Below it in the drawing we have a part of the chromosphere, including a "flaring," which has been since called a "radiance" by the American astronomers. Fig. 4 was the last photograph taken, and here it is seen that the Great Horn is nearly eclipsed, and that the chromosphere on the opposite side of the sun is now exposed, including a strange animallike form, which much struck the observers. An examination into the structure of the Great Horn is not the least interesting part of the report.

Major Tennant thus sums up his results :-

First.-The corona is the atmosphere of the sun not se'f-luminous, but shining by reflected light. It is evidenced both by the spectroscope and polariscope that this is the case, but there is one reservation to be made. The polariscope has shown clearly that the light of the brightest part of the corona is mainly reflected; but, looking to the flare which is seen in photographs No. 2 and 3 , it seems impossible to doubt that in those places there must have been some inherent luminosity in the corona; unless indeed we consider the flare as a modified form of protuberance. It is, I think, now certain that luminous gas issues from what is more strictly the sun, and I apprehend this flare to be some of this.

Secondly. - The Great Horn certainly was composed of incandescent vapours, and probably all the brilliant protuberances are the same. In the Great Horn these vapours were hydrogen, sodium, and magnesium. It seems to me perfectly certain that the ignited hydrogen issued from the sun itself, and that it carried up with it the light vapours of sodium and magnesium far above the level at which they would naturally lie; hydrogen naturally would be the very highest of the gaseous vapours, and consequently the coolest; if, however, it were set free at the surface of the sun it would be intensely hot, and seek, with great violence, to ascend, in which process, if there be a stratum of heated vapours, such as is usually believed to exist round the sun, the hydrogen would partly displace and carry up these vapours, and the lighter would be taken in preference. In fact, in this case it has carried the two lightest, and that of iron, which is so much heavier (I think we may presume this from the absence of the line corresponding to E), was either displaced or dropped sooner than the height at which I observed. Photograph No. I shows that there were two jets of vapour concerned in forming this Horn. One, the largest and most northerly, is seen nearly perpendicularly to the limb, and seems also to have been the most luminous; the other issues about $20,000^{*}$ miles towards the south, and at an angle. They met at a height of some $16, \infty 00^{*}$ miles, and the result was the rapid vorticose motion, which is evidenced in all the photographs as having existed in the upper portion. I believe $I$ have the good fortune to be the first person to recognise such a phenomenon.

I think that gases or vapours issuing quietly from the solas surface would tend locally to raise the superincumbent ignited vapours. In places where they were most abundantly given out the elevation would be greatest, everywhere the gas. would leak through in streams, producing occasionally such phenomena as the flare I have spoken of in Nos. 2 and 3 . For a time the ignited vapour might, I think, form, as it were, a case for the light included gas, which would be to all appearance inflated like the animal figure in No. 6: Soon, however, the slightly coherent casing would be burst and the gaseous contents would issue freely the heavier vapours would, of course, to some extent be carried off by the gas, but would mainly settle down in small masses. Such, I think, is the state depicted in the southern protuberance of No. $x$.

I would now draw attention to Plate No. I, and the glare and liminous stratum. If that glare be from sunlight, it must, I think, be acknowledged that the remaining ray was but small. The luminous nearly even stratum then is not the sun; but it is intensely bright, so much so, that nowhere is it lost in the solar glare. Its height is but small (I estimate it at 7,200 miles), and I believe it to be the mass of heavy luminous vapours, to whose elective absorption we owe the Fraunhofer lines in the solar spectrum. At the north end of this stratum near the Great Horn, it is broken into beads of light ; $\dagger$ and $I$ am disposed to think * These dimensions refer to the projections on a plane perpendicular to the visual ray.

$t$ This is the same place where Captain Branfill saw beads. these are the veritable Baily's beads, of which I have always felt that the description would be difficult to apply to sunlight ; I mean the statement which has been made of the light being silvery, \&c. If these beads are really phenomena of the absorbing stratum, one can well understand the use of such terms.

In an addendum, in which the author's theory is attempted to be maintained, Major Tennant refers to the work which has been done in this country between the eclipse and the issue of the report. He considers that the sun is surrounded by an atmosphere sufficiently dense to reflect the solar light, but it is not explained why a continuous spectrum and not the solar spectrum is actually reflected; and that the hydrogen is enveloped in a denser atmosphere, resisting its diffusion and expansion, but why the spectrum of this atmosphere is so simple is not explained.

The author concludes by acknowledging the services rendered by Mr. De la Rue in the preparation of the report.

\section{FALL OF A METEORITE}

THE Director of the Meteorological Office has forwarded the following extract from a letter from $M$. Coumbary, Director of the Imperial Meteorological Observatory at Constantinople for publication :-

Constantinople, 9 mars, I87o

Mon cher Monsieur,-Je saisis l'occasion qui m'est offerte pour vous transmettre la communication que vient de nous faire $M$. Carabella, Directeur des Affaires Etrangères du Vilayet de Tripoli de Barbaru.

" "Tripoli, 2 février, 1870 (Fezzan), latitude $26^{\circ} \mathrm{N}$., longi i860 i869, il est tombé à l'est de la ville, vers le soir, un immense globe de feu, mésurant un mètre à peu près de diamètre, et qu'au moment où il a touché terre il s'en est détaché de fortes étincelles qui, en se produisant, claquaient comme des coups de pistolet, et exhalaient une odeur que l'on n'a pas specifiée. Cet aërolithe est tombé à peu de distance d'un groupe de plusieurs arabes, parmi lesquels se trouvait le Chiok-el-Veled de Mourzouk. Ceux-ci en ont été tellement éffrayés qu'ils ont immédiatement déchargé leurs fusils sur ce monstre incompréhensible. Son Excellence Ali Riza Pacha a écrit a Mourzouk pour faire transporter ici l'aërolithe; au cas probable où il soit trop pesant on le mettra en pieces; nous vous enverrons tout cela. Il y a un mois de voyage d'ici à Mourzouk. Ce n'est done que dans deux mois à peu près que nous pourrons vous faire cette expédition. S'il peut vous être de quelque intérêt de le savoir, je vous dirai que quelques voyageurs du Waddad que j'interrogeais m'ont dit que le Sultan du Waddad et tous les grands personnages de sa cour ont des poignards; des sabres et des lances faits avec du fer tombé du ciel, et quil en tombe de grandes quantités dans $\begin{array}{ll}\text { ce paystla } & \text { (Sdi) }\end{array}$

Je crois devoir vous informer qu'au reçu de cette lettre et 2 la suite des démarches nécessaires, S.A. le Grand Vizir a bien voulu faire donner ordre immédiatement par télégraphe à Tripoli, pour que l'on prenne les mesures nécessaires afin que ce météorite nous parvienne intact - Recevez, cher monsieur, \&c. (Sd.) Aristide CoUmbakt

\section{NOTES}

ON the $5^{\text {th }}$ of March died at Vienna, Joseph Redtenbacher, Professor of Chemistry at the University. He was born in 1810 , and studied under Eichig, conjointly with whom he published a determination of the atomic weight of carbon, and several other memoirs. His principal merit consists in the discovery of acrolein and acrylic acid. Most of his papers were published between 1839 and 1848 . With his death chemistry in Austria passes entirely into younger hands; his colleague, Professor Schröber, the discoverer of amorphous phosphorus, having lately been nominated Master of the Mint, and replaced in his chair by Illasiwetz. The succession of Redtenbacher will be divided into two parts, and the building of a new laboratory 